KRZYSZTOF BIZIO*

\section{W stronę słońca. Uwagi o wpływie światla słonecznego na modernistyczne kompozycje w architekturze mieszkaniowej}

Toward the Sun. Comments on the influence of the sunlight on the modernist compositions in housing architecture

\section{Streszczenie}

Tematem artykułu jest analiza wybranych modernistycznych przykładów kompozycji architektury mieszkaniowej, w których dostrzec można wplywy finspiracje wynikające z chęci wykorzystania sposobów operowania swiatla slonecznego. Analizy przeprowadzono w odniesieniu do rozwiązań urbanistycznych oraz architektonicznych. Zapewnienie właściwych warunków doświetlenia swiattem stonecznym, obok potrzeby stworzenia dogodnych warunków przewietrzania, dostępu do terenów rekreacyjnych i innych uwarunkowań higieniczno-sanitarnych, stały się w początkach XX w. jednym z fundamentów ruchu modernistycznego W artykule omówiono-z perspektywy dostępu do swialla slonecznego, kolejne formy rozwoju kompozycji urbanistycznej (nowy typ kwartalu zwartego, kompozyce liniowe, uklady wolno stojace i punklowe). Wodniesieniu do rozwazzań architektonicznych omówiono rozbiezne (co do sposobu wykorzystania swiatta słonecznego) przyklady z pớnocy Europy - gdzie zapotrzebowanie

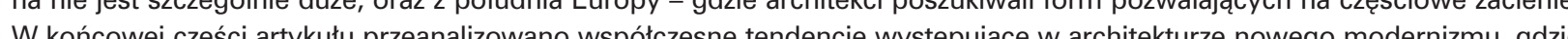
wykorzystanie światta słonecznego stanowi także inspirację w tworzeniu rozwiazzań architektonicznych.

\section{Abstract}

The subject of this article is an analysis of selected examples of the modernist housing architecture, in which influences and inspirations resulting from the intention to incorporate the means of operating the sunlight can be observed. Analyses were performed with reference to urban and architectural solutions. Ensuring proper lighting conditions, in addition to the necessity of creating suitable ventilation conditions, the accessibility of recreational areas and other hygiene-sanitary conditions, has become one of the foundations of modernist movement at the beginning of 20th century. The article discusses the following perspective of access to sunlight. According to the architectural solutions (depending on different approaches toward incorporating sunlight) the article discusses miscellaneous examples across Europe - north, where the demand for it is particularly high, and southern efforts nurturing partial shading in their designs. The final part of the article examines contemporary trends in the architecture of modernism, where the use of sunlight is also an inspiration for architectural solutions.

Słowa kluczowe: Światto słoneczne, architektura mieszkaniowa, modernizm, kompozycja urbanistyczna, kompozycja architektoniczna

\section{W stronę światta}

W fundamentalnym dla ruchu modernistycznego dziele W strone architektury (Vers une architecture) Le Corbusier zdefiniował swoje wyobrazenie o architekturze i mieście przyszłości, w których dostępność do światła słonecznego miałaby być jednym z fundamentów nowoczesności. Dażenie to pozostające w opozycji wobec znacznej części rozwiązań architektury mieszkaniowej z końca XIX w., stało się fundamen-

\section{Toward the Sun}

In Toward an architecture (Vers une architecture) his fundamental work for modernist movemen work Le Corbusier determined his notion of the architecture and the city of the future, in which the access to sunlight ought to be one of the fundagreat deal of housing architecture solutions from tem modernizmu. W ciągu XX i na początku XXI w. zapewnieinspiracją do tworzenia coraz to nowszych rozwiazzań formalnych. Sledząc kolejne dekady zmagań architektów wywodzacych się z nurtu modernistycznego widoczne stają sie jednak odmienne efekty tych inspiracji. W pierwszych dziesieccioleciach XX w, pod wpływem nurtów racjonalistycznych, obserwować można było próby wprowadzania rozwiązań, które wrecz w inżynierski sposób miały gwarantowad wręcz W inżyniersk sposób mialy gwarantowac niezbędne warunki nasłonecznia. W kós waz wu respar cia gu respeḱ ó wy sty sozwala to spojzec na sw prym wark warunkow jego obecnosci w modemistycznej architekturze mieszkaniowej - jako na jeden z waźlejsych czyn ków wpływających zarowno na rozwiązania urbanistyczne, jak rozwiązania architektoniczne.

Kluczowym dla zrozumienia znaczenia światła słonecznego w kompozycji modernistycznej architektury mieszkaniowe wydaje się analiza rozwiązan z konca XIX w. i początku XX w. dla której modernizm stanowic miał swoisty kontrapunkt. Intensywne wykorzystanie terenu powodowało powstanie zabudowy o duzej gęstości, niewielkich terenach zielonych oraz mieszkan, kore często posiadaly slabe nastonecznienie, a w przypadku części zabudowy wręcz całkowity brak dostępu promieni słonecznych (il. 1). Ideowym gestem sprzeciwu wobec zastanej izeczywistosci uznac można w tym kontekście paryski projekt Plan Voisin Le Corbusiera z 1925 r. Choc z dzisiejszej perspektywy trudno o akceptację tak radykalnych postulatów, to jednak projekt ten oddawał nastroje społeczne i symboliczna drogę w stronę światła - którą odbyć miała cała architektura XX w.

2. Reforma zabudowy kwartałowej

Zwarte kwartały zabudowy mieszkaniowej stanowity w Eumopie podstawowe tworzywo kompozycii od czasów starożytnych. Naturam modernistóm kompozycil kwatelowych, w sposób któn

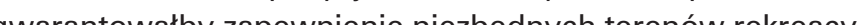

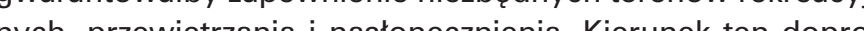
wachi prewietzania i no niowej, która stała się popularna w okresie międzywojenny. the end of the 19th century, became the foundation ing 20 th and in the beginning of 21st century, ensuring optimum insolation conditions still remains an inspiration to create more and more recent formal solutions. However, revising the following decades of struggle by architects originating from modernist movement, various results of these inspirations become apparent. In the early decades of 20th century, under the influence of rawhich in almost enginering way were supposed which in almost enghe ring way were supposed to be observed. In following decades, especially in the late phase of modernism, more expressive solutions came to the fore, however still respectful of the priority of insolation conditions. This knowledge allows to perceive the sunlight and striving for its optimal presence conditions in modernist housing architecture as one of the most crucial factor affecting both urban and architectural solutions.

Crucial for understanding the importance of sunlight 作 of the solutions from the end of the 19th and the serntury, for which modernism is f thes to be the counterpoint. An intense use 政 often bulding, small green areas and flats which the buildins insolation, and in case of some of (iil. 1) Le Corbus's Pain accoss from 1925 can be considered as ideolosical gesture of opposition to reality. Although from today's perspective it is difficult to accept such radical postlates, this project reflected social moods as well as symbolic path towards the Sun - which had yet to be taken by the whole 20th century architecture.

2. Reform of building quarters

The compact quarters of residential housing have been the primary structure element across Europe ever since antiquity. It has become natura for modernists to modify quarter structures in the way that would guarantee necessary recreationa areas, ventilation and insolation. This direction has led to the development of new type of urban housing, which become popular during the interwar

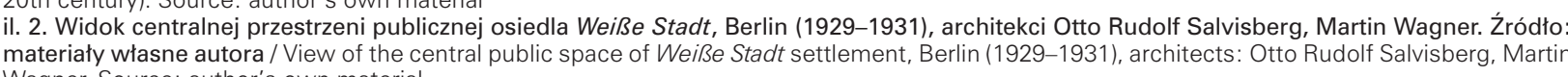

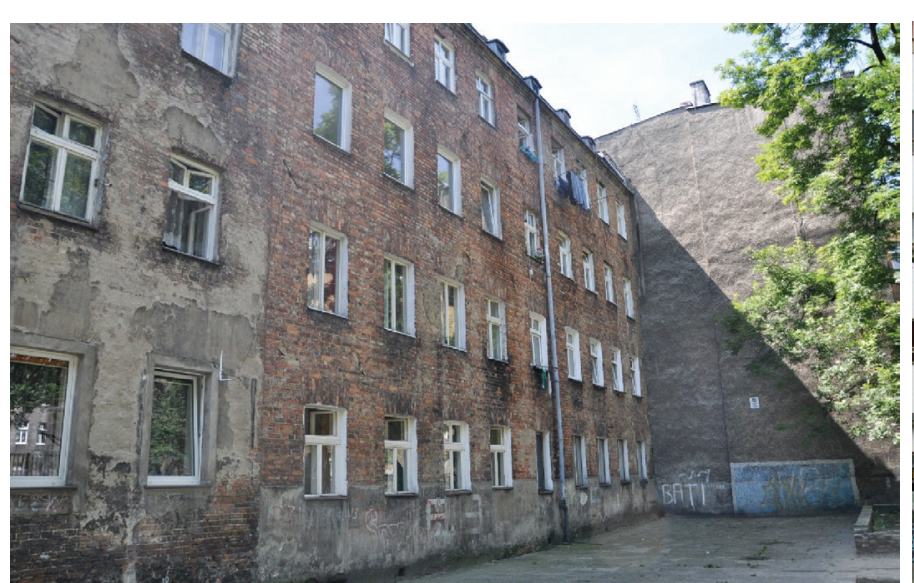

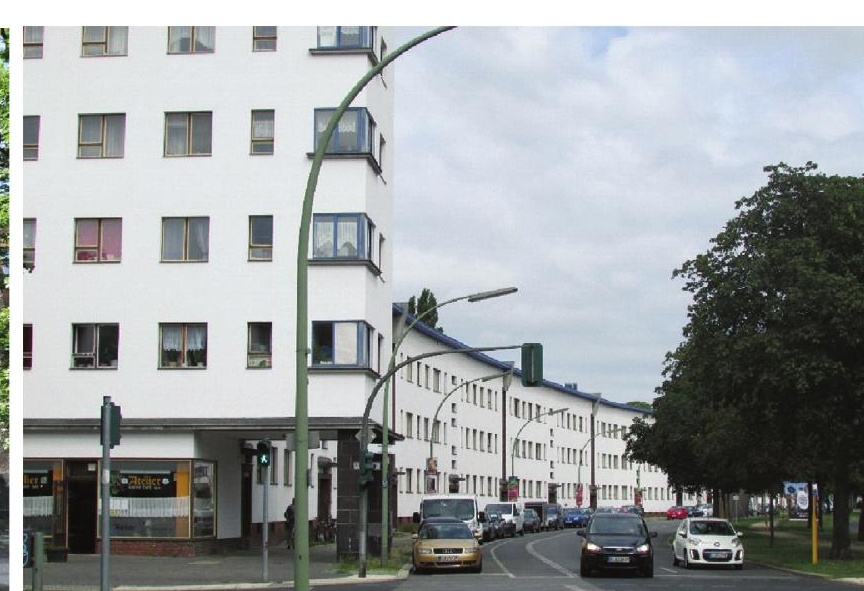


Powstałe w tamtym czasie założenia najczęściej charakterynych modułów zabudowy obrzeżnej, z centralnie umieszczoną przestrzenią zieloną przeznaczona dla ogółu mieszkańców. Taki typ zabudowy występował w wielu krajach europejskich, w tym także w miastach polskich. Awangardowa formę tych poszukiwań na przełomie lat 20. i 30. XX w. prezentowała także część berlińskich osiedli, w których to twórcy w płynny sposób faczyli zabudowe obrezna z ciagami zabudowy ny sposób lączllá poszukizán stalo sie stworzenie kompromisowej kompozy-

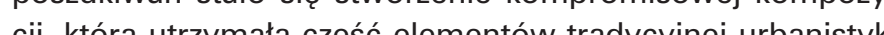
(pierzeja, ulica, plac), tworac rownocz (piesze, ulica, plac), tworzac równoczośnie warunki nowobyly dobre wawisk mieszkaniowego - Körego symbolem byly dobre was dem takiego razhzan jest betlinskej osiele Weiße Stadt. W kompozycji unbanistycznej na uwage zasluguje tu charakterystyczne dla owczesnych rozwiązan fukowate wygięcie części elewacil (1. 2), co buduje intersujące efekty światocieniowe. Takze w ukladach funkcjonalnych mieszkan powstających w tego typu osiedlach widoczny jest wpływ warunków nasłonecznienia. W ich rozwiązaniach nastapiło m.in. zmniejszenie glębokossci traktow, czy też wprowadzanie od strony nasłonecznionej balkonów i loggii.

\section{Kompozycje liniowe}

Jako bezpośrednią odpowiedź na próbę stworzenia optymalnych warunkow nasłonecznienia w osiedlach mieszkaniowych uznać można rozwój układów liniowych, które najczęściej przybierały orientację południkową. Choć koncepcje Miasta Linearnego (Ciudad Lineal), wywodzić można z twórczości Arturo Soria y Mata, który oparł ją na zagadnieniach komunikacyjnych, to jednak dopiero rozwój idei modernistycznych i powiazzanie ich z optymalizacja dostepu światta wpłynety na i popularyzacie. Układy południkowe w okresie miedzywojennym tworzono gtównie w oparciu o powtarzie ne sekcje klatkow lub w prypadku bardziej progresynych rozwiazań stosow urbanistyczoch prybieraly one najczście forme prostych, ustawionych rów paybiastych ustaw Wzocown pray Wzorcomy kom(ii. 3.), krorazosta zaprojektowa osiedla im. Cata Legien (il. 3.), która została zaprojektowana przez Bruno Tauta.

featured disciplined geometry made of perimeter with central green area allotted to residents.

This type of building was present in many European countries, including Polish cities. At the turn of the 1920s and 1930s the avant-garde form of these searches was represented in Berlin Modernism Housing Estates, in which creators seamlessly connected perimeter buildings with the building attempts is creating an uncompromised composition capable of maintaining some of the former urban planning utilities (frontage, street, square) while also providing a firm base for the rise of the modern housing environment - with good insolation status for an emblem.

Perfect example of such solution is Weiße Stadt the housing estate in Berlin. Noteworthy in urba composition of this project is a bending curve of the elevation piece (ill. 2) typical of solutions at the time and creating an intriguing illumination effects. The influence of solar exposure consideration is also visible in the functional layout of the built-in flats. Its solutions include the building outline reand loggias from the sunlit side of a building.

3. Linear composition

The development of predominatingly south-orimeridion on answer to an attempt to create the optimal insolation scenario in the housing projects. And although the concept of the Linear City (Ciudad Lineal) can be derived from the works of Arturo Soria y Mata based on communication issues, no sooner had it been popularised than the modernist ideas along with the optimization of the access to sunlight developed. During the interwar period longitudina layouts were mainly based on repetitive staircase units sets or gallery systems, were it for a more progressive solutions. In terms of urban planning solutions, they usually took the form of simple paallel lines of development, separated by driveways and green belts. The urban composition of the Car Sagan's estate in Berlin (ill. 3), designed by Brun

This type of urban planning was being developed

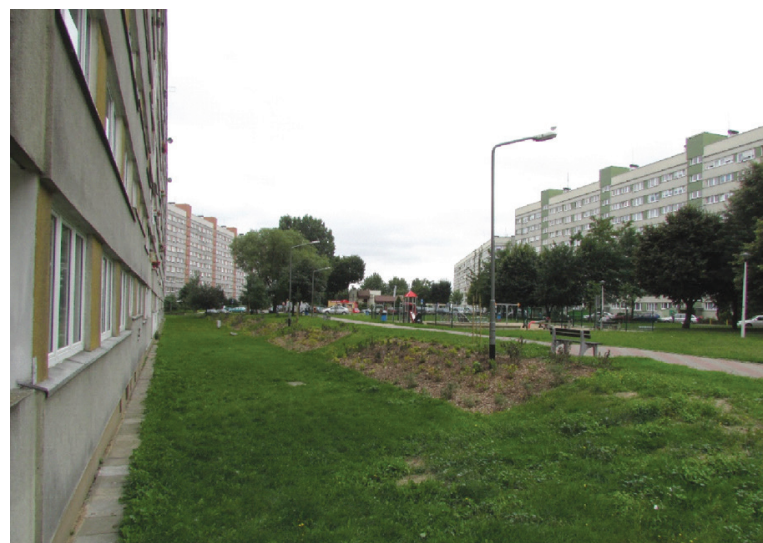

W kolejnych dekadach ten typ urbanistyki był rozwijany. ciach historycznych miast, które ulegały przebudowie po zniszczeniach II wojny światowej, co w wielu przypadkach spotyka wojem nowych idei formalnych, zmodyfikowano także sposoby komponowania osiedli wykorzystujacych układy liniowe. Pojawiła sie gama rozwiazzá oparta na formach krzywoliniowych², oraz swobodniej, a węcz rzeźbiarsko wykorzystanie nistyczny szczecińskiego osiedla im. A. Kaliny (il. 4.).

\section{Kompozycje wolno stojace i punktowe}

Po II wojnie światowej doszło do masowej realizacji modernistycznych osiedli mieszkaniowych, które powstawały zarówno w obszarach odbudowywanych śródmieść, jak i na terenach nowej urbanizacji. Obserwować można było postępujące umasowienie zasad powstawania architektury mieszkaniowej, z dzisiejszej perspektywy podnieść też można za pewne wiele niedostatków jej form, nie zmienia to to jednak unków nasłonecznienia pozostała wciąz aktualna. wienie kolejnych schematów funkcjonalnych.

Znaczenie, jakie przywiązywano w tamtym okresie do zapewnienia własciwych warunków nasłonecznienia, widoczn było szczególnie w srodmiejskich uzupełniniach, gdzie nowe, ekstensywne formy zabudowy sąsiadowały często $z$ intensywną, historyczną zabudową kwartałową. Jednym z poligonów doświadczeń nowej architektury mieszkaniowej stało się powstanie w 1957 r. berlińskiego osiedla Hansaviertel, które zrealizowano w miejscu zniszczonego układu historycznego. W ramach tej wystawy architektonicznej powstało szereg budynków, które miały mieć charakter rozwiazzań wzorcowych, a najcześciej wykorzystywanym schematem funkcjonal stały sie podłuże, wolnostojace, średniowysokie budynk mieszke. W tym kontekście interesujace sa dwa przyn rozwiazań, których autoksy w odmienny sposób zryentady li wobec stóca projektowane przez siebie budyni. Water Gropius i The Architects Collaborative (TAC) zaproponowal się współcześnie z krytyką! . W latach 60. i 70. XX w., wraz z rozwych $^{2}$ oraz swobodniej, a wreecz rzeźbiarsko wykorzystanie faktu - iż dążenie do zapewnienia możliwie najlepszych waPozwoliło to na udoskonozostała wciąz aktualna.

over the following decades. During the post-war period, it was also implemented in downtowns of historic towns having undergone reconstruction after the destruction of World War II, which recently has become widely criticised'. In the 1960 s and 1970s along with the development of new formal deas, the ways of composing settlements using linear systems have also been modified. A range of solutions based on curvilinear forms $\mathrm{s}^{2}$, and also curred; a mong the examples - urban lavout of A. Kalina's housing estate in Szczecin (ill. 4).

\section{Detached and tower block settings}

After World War II a mass realization of modernist housing estates has occurred. These estates were created both in the reconstructed areas of the city and the newly urbanised areas. Progressive massification of the principles of the setting up of hous ing architecture could be observed. From today's form however striving to ensure the bings of is ins, how the refinement, and above all-the massification of further functional schemes.

The importance attached to the proper insolation conditions at the time was especially visible in the downtowns, where new extensive forms of development were often adjacent to the intensive, historical housing quarters. The rise of the Hansaviertel estate in Berlin in 1957, which was created at the site of the destroyed historical setting, has become one of the experimental areas of the new residential architecture. Within this architectural exhibition a series of buildings were created which were supposed to be the model solutions, and the most frequently used functional scheme was longitudnal, detached, medium-sized residential buildings the ing, in which the authors set up their buildings in ways varying in relation to the sun. Walter Gropius atitudinating with a distinctively curved soud facade. This curve allowed them the extension of

il. 5. Fragment rzutu pietra powtarzalnego, Berlin, budynek na wystawe Interbau Hansaviertel (1957), architekt Walter Gropius i The Architects
Collaborative (TAC). Zródto: materiaty KAWTiMP ZUT / Fragment of repettitive floor plan, Berlin, building for the Interbau Hansaviertel exhibition (1957), architect Walter Gropius and The Architects Collaborative (TACl. Source: KAWTiMP ZUT materials
il. 6 . Model budynku na wystawe Interbau Hansaviertel (1957), Berlin, architekt Oscar Niemeyer. Zrótho: materiaty KAWTiMP ZUT / Model of

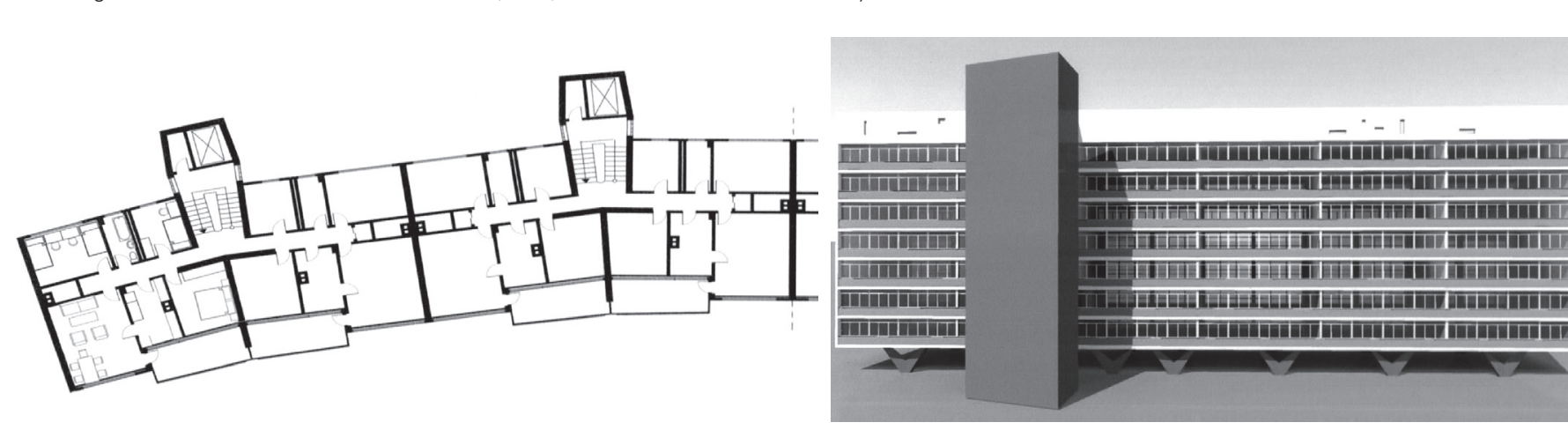


układ równoleżnikowy z charakterystycznie wygiętą elewacją południowa. Zakrzwienie to pozwolito na zwiekszenie powierzchni nasłonecznionej elewacji i stworzyło ciekawe efekty światłocieniowe (il. 5).

Częściej stosowanym ustawieniem budynków pozostał jednak układ południkowy, który został zastosowany w berlińskim projekcie Oscara Niemeyera (il. 6). Niemeyer podobnie jak Gropius wykorzystał w swojej koncepcji układ klatkowy. Jednak przez wprowadzenie w centralna cześć traktu niedoświetlonych świattem stonozym klatek schodowych, udoto mu sie wykorzystać do doświetlenia pokoi mieszkanych catośc wschodniej i zachodniej elewaci. Cecha charakterycalośc w wykzystac do doswietlenia pokoi mieszka hych styczna projektu, kích by budynk, która wetni pokyto uktadem logii Poprez tek

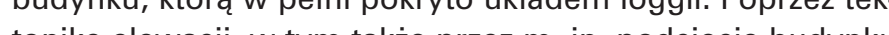
tonike elewaji, w tym takize przez m. in. podcęcie budynku w parterze, pasmowy ukad cohnętych okien, czy teź swobodna kompozycje otworow okiennych w ostatniej kondygnacji, udało się autorowi stworzyć interesujące rozwiązania

Innym schematem kompozycyjnym stały się punktowe budynki wysokie. W rozwiązaniach tych klatka schodowa umieszczana była najczęściej w centrum, co pozwało także na pełne wykorzystanie wszystkich elewacji. Rozwiązania takie doczekaly się wielu warantow, a jedne z najciekawszych zaprojektowane zostały przez Ludwiga Miesa van der Rohe. Pierwsze idee szklanych wieżowców zaproponowane zostały przez niego już na poczatku lat 20 . XX w. $^{3}$ ale praktyczna realizacja tych idei nastapiła dopiero po jego przyjeździe do USA. Najbardziej znanym projektem $z$ tego okresu pozostaja budynki apartamentowe powstałe w 1957 r. przy Shore Lake 860-880 w Chicago (il. 7). Cechą charakterystyczną tego rozwiązania stało się maksymalne otwarcie na światło słoneczne, które zrealizowano poprzez umieszczenie pomieszczen mieszkalnych wzdłuż przeszklonych elewacji.

\section{il. 7. Rzut modutu mieszkalnego, Chicago, Apartamenty przy Short Lake 860-880 (1957), architekt Mies van der Rohe. Ż́ródto: materiaty KAWT
iMP ZUU / Residential module projection, Chicago, Apartments by Short Lake $860-880$ (1957), architect Mies van der Rohe. Source: KAWTiMP ZUT} iil.8. R. Rzut pietrra powtarzalnego, Stuttgart, budynek Romeo i Julia (1954-1959), architekt Hans Scharoun. Żródto: materiały KAWTiMP ZUT / Re-
peating floor plan, Stuttgart, Romeo i Juliet building (1954-1959), architect Hans Scharoun. Source: KAWTiMP ZUT materials
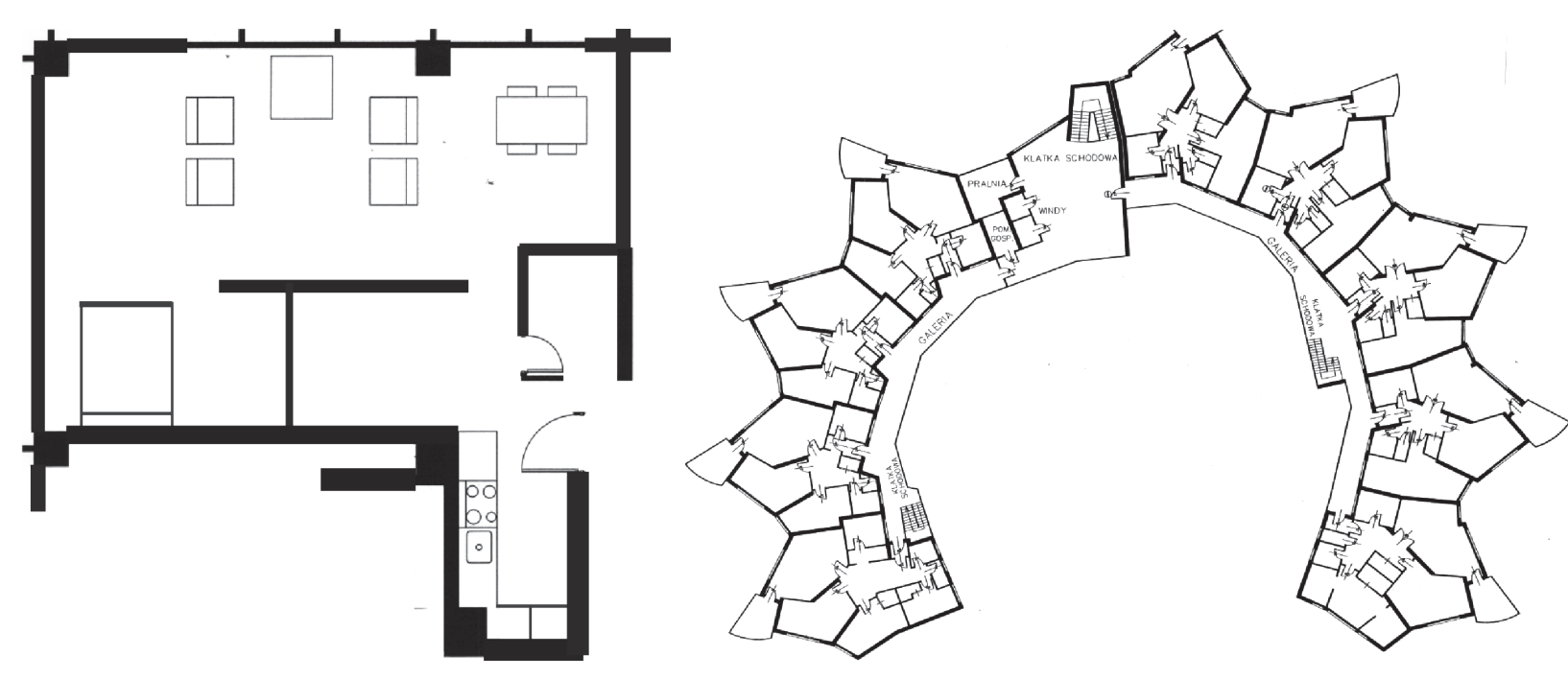

Pośród budynków powstałych po II wojnie światowej na szczególną uwage zaslugują autorskie wstały dzięki inspiracji wynikającej ze sposobu operowania światła słonecznego, który wymyka się oczywistym klasyfikacjom. Przykładem takiego dzieła jest powstały w Stuttgarcie w latach 1954-1959 kompleks budynków Romeo i Julia autorstwa Hansa Scharouna (il. 8). Centralnym punktem założenia jest tu ekspresyina forma wielokondygnacyjnego budynk galeriowego skupionego wokót pótotwartego dziedzińca In-

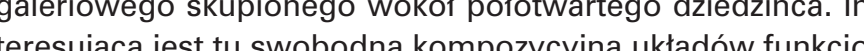
nalnych poszczególnych mieszkań, które zwieńczono rojzem lo

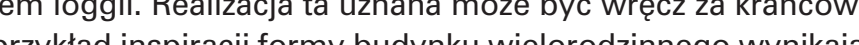

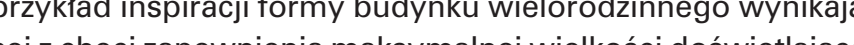
cejz chęci zal

\section{5. „Światło północy”}

Modernizm pomimo swych korzeni wywodzących się ze stylu międzynarodowego posiadał także lokalne odmiany. Stosowane formy były w takich przypadkach efektem indywidual ności twórców, ale wynikały takze z uwarunkowań środow skowych, spośród których jedną z ważniejszych okazały się warunki nasłonecznienia. Proces ten szczególnie interesując przebiegał w krajach, w których dostęp do światła słonecznego jest utrudniony, co postawiło przed architektami koniecznośc poszukiwania rozwiązań formalnych polepszających warunki nasłonecznienia.

Starania te prześledzić można w projektach mieszkaniowych Alvara Aalto, który stał się ojcem duchowym skandynawskiego modernizmu. Szczytowym osiągnięciem Aalto w zakresie rozwiązań architektury jednorodzinnej stała się Villa Mairea, którą zrealizowano w Noormarkuu w latach 1938-1939. Podporządkowanie kompozycji architektonicznej warunkom nasłonecznienia widoczne jest tu w ogólnym rozplanowani budynku, które zbliżone jest do litery L (il. 9). Pozwolito to $n$ otwarci, przestrzeni skupionej wokół otwartego dziedzińca Ten model rozplanowania wykorzystywany był takze przez innych twórców skandynawskich. Interesujace w tym zzez inla staden w Lund $z$ Telsing $\varnothing$ cie zblizonym takze do L, a w centrum domu umi so ksztarcie zbliźny

W twórczości Aalto warto także zwrócić uwage na zastosowane detale architektoniczne poprawiające penetrację słońca we wnętrzach. W Villa Mairea zastosował on w gorzej nasłonecznionych elewacjach "tapacze światta" - rodzaj niesymetrycznych wykuszy skierowanych wieksza płaszczyzna w kierunku promieni słonecznych. W budynkach użyteczności publicznej stosował także świetliki instalowane $w$ dachu', czy też występujące w ciągu całej jego kariery duże płaszczyzny światła sztucznego lokowane $w$ centralnych przestrzeniach reprezentacyjnych budynku.

Za najbardziej spektakularny przykład odzwierciedlający dążenie do wykorzystania światła słonecznego uznać można projekt Aalto-Hochhaus, który powstał w 1962 r. w Bremie. Ten liczaç 22 kondygnacje budynek przeznaczony został dla
Scharoun's Romeo and Juliet complex of buildings built up in Stuttgart in 1954-1959 (Fig.8.) is but another example of such work. The central point of the complex is the expressive form of a multi-storey gallery building wrapped around a semi-open courtyard. Particularly striking here is the compositional liberty of respective flats functional layouts, having been topped with loggias of sort. This realization can be considered as an ut inspiration resulting from the desire to provide maximum surface for the sun exposed facade.

\section{5. "The light of the North"}

In spite of its international style roots, the modernism also had its local varieties. Forms tse employed in such cases were the result of the individuality of the creators, but also of the environmental factors, among many other, namely insolawas thed out to be the key factor. This process was particularly interesting in countries where was limited, forcing architects improvements.

This search can be traced in the housing projects of Alvar Aalto, who became the spiritual father of Scandinavian modernism. Aalto's peak achievement in single-family architecture solutions was the Villa Mairea that was built in Noormarku in position with the condition of sunlight is evident in the general byout of the building is evident the letter $L$ (ill 9). This allowed opening the space round the open couttyard This layou model was also used by other Scandinavian creators.

Jørn Utzon's proposals were fairly interesting in this subject. In his 1958 Planetstaden housing estate project in Lund and the 1960 Kingohusene housing estate project in Helsingør, he implemented an L-shaped layout in a one-storey house and set up a private garden in its center.

The architectural details used to improve the penetration of the sunlight through the interiors are also noteworthy in Aalto's work. In Villa Mairea, he used "sun catchers" in the under illuminated facades - a kind of asymmetric oriels directed with a larger plane toward the sun. In his public comis sions, he wold fordy use skylights installed the roof, and throughout his career, large areas the cerilding. Alto's Hochhaus project, which was bu

1962 acular example reflecting the desire to harnes the sunlight. This 22-storey building was de signed for single and childless people. Southish orientation of the building allowed the architect to design a curvilinear, malleable wall from the west side (ill. 10).

Its form was probably intended by the author to create the widest possible plane illuminating the living spaces. 


\section{Płynna nowoczesność}

Wprowadzone do wspołczesnej humanistyki przez Zygmunta Baumana pojęcie płynnej nowoczesnosci (liquid modernity) miało w zamierzeniu autora w skrotowy sposob opisywac zmienność i fragmentaryczność wspótczesności. Kategorie tą zastosować można także do teorii i praktyki współczesnej architektury Postawa ta wystepuje u cześci twórców nowego modernizmu, którzy wykorzystujac formalistyke tradycyinego modernizmu i odcinajac sie od jego spotecznych idei wzbogacaja natom o swóście pojety architekt idiczy homor, wieloznaczínci, a czesto wrecz celowa prymity hui uproszcze które chrakterystyczne sa dla wspótczesje kultury masowej. W tej nowej, zabawie w archistue" sne ku tury mawe. W We nowiatto naturalne odgrywa po raz kor

dejścia może być kontrowersyjna twórczość Bjarke Ingels Group i projekt 8 House. Ten powstały W Kopenhadze w pierwszym dziesięcioleciu XXI w. budynek. (ii. 13) zgodnie ze swą nazwa, zakomponowano $w$ kształcie cyfry 8 . W ukladzle funkcjonalnym budynku na podkreslenie zasługuje sposób prowadzenia komunikacji wewnętrznej, który podporządkowany został zapewnieniu dobrych warunków nasłonecznienia i w istocie zadecydował o formalnym wyrazie przestrzeni.

W kontekście przekształceń klasycznych rozwiązań modernizmu traktowac można także projekt ideowy wielorodzinnego budynku Frøsilo (il. 14) autorstwa holenderskiego biura MVRDV ${ }^{11}$, który zaprojektowano w strefie nadwodnej Kopenhagi. Szczególnie interesująca w tej idei jest swoboda kształtowania krzywoliniowej bryły. Swiatło, podobnie jak w szklanych koncepcjach Miesa van der Rohe, penetruje tu pełny trakt budynku, a zasada jego dostępności jest naczelna w sposobie formowania całej bryły. W obydwu projektach wyraźna jest aprioryczność założeń formalnych, które nie wynikaja jednak z logiki konstrukcji lub optymalizacji funkcii, ale sa raczej efektem subiektywnych, a wrecz chimerycznych (bo niewytumaczalo wania) założeń formalnych. tecture. This attitude describes well some creators traditional modernism, stripping it away from its social ideas, enriching it with a particular architectura sense of humour, ambiguity, and often even delibe ate primitivisation and simplification, which are typ cal of modern mass culture. In this new "game of architecture", natural light once again plays a decisive Tole in creating an architectural form

The Bjarke Ingels Group proach. This built in Copenhagen in the first such apof the 21st century building (Fig. 13) according to its name, was 8-shape composed

What is noteworthy in the functional layout of the building, is that the way of internal communication was lead in subordination to ensure the good sunlight exposure and in fact impacted the forma expression of the space.

design of the multi-family building Frøsilo (ill. 14), set in the waterfront area of Copenhagen by the Dutch MVRDVoffice ${ }^{10}$, can als be taken into consideration in the context of the transformating the standard modernist solutions. Particularly entertaining in this idea is the freedom of forming the curvilinear body. The light here, penetrates the full path of the building as in Mie van der Rohe's glass concepts, and its principle of accessibility is the main way of forming the whole a priori nure, derived not from the reasoning hind construction or functional sustainability, but a result of somehow biased, whimsical even (therefore inexplicable by the means of critical thinking formal presumtions.

\section{Summary}

Ensuring of the optimum sunlight accessibility was the inspiration for creating the individual solution the 20 th the 20 and

il. 13. Rzut kondygnacji, Kopenhaga, budynek 8 Houses (2010), architekt Bjarke Ingels Group. Żródto: materiały KAWTiMP ZUT / Floor plan Copenhagen, 8 Houses building (2010), architect Bjarke Ingels Group. Source: KAWTiMP ZUT material KAWTiMP ZUT / Frag
KAWTiMP ZUT materia
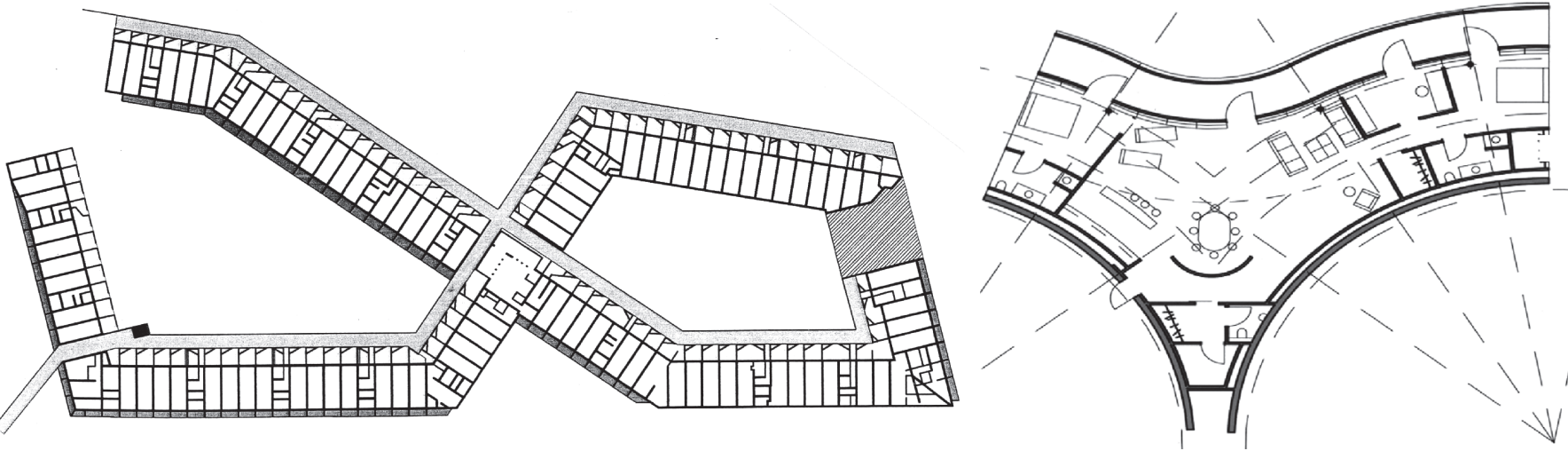

9. Podsumowanie

Zapewnienie optymalnych warunków dostepu światła słonecznego stanowito inspiracje do tworzenia indywidua rozwiązań formalnych zespołów urbanistycznych i budynków mieszkalnych w XX i na początku XXI w. W okresie formowania się idei modernizmu element ten, wraz z potrzebą zapewnienia właściwej jakości terenów rekreacyinych, przestrzen wokół budynków, przewietrzania i właściwych warunków higieniczno-sanitarnych - stanowit wrecz synonim nowoczes-

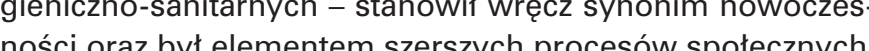
Wynikiem tych procesów staty sie różnorodn spocenych. formalne prowa for $x$. czic model trady zy reformow

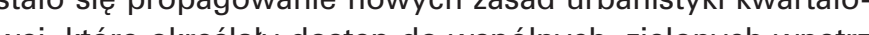
wej, ktore okreslaly dostęp do wspónych, zlelonych whętrz kwartalowy horaz zapewnienie wasciwych wartosci nasiojej naczelnej roli) stało się promowanie schematów zabudojej naczelnej roli) stało się promowanie scl

wy liniowej, wolnostojaceji pu Elementem, który w sposób szczególny wpłynął na sposoby wykorzystania ekspozycji słonecznej były warunki wynikające z szerokości geograficznej, na której znajdowały się zespoły mieszkaniowe. O ile bowiem w przypadku lokalizacji na północy Europy - dązono do otwarcia przestrzeni na penetrację słońca, to w przypadku lokalizacji południowych - starano się wprowadzac rozwiązania utrudniające dostęp. Wpłynęło to zarówno na rozplanowanie poszczegolnych pomieszczeń, jak i przyczyniło się do stworzenia indywidualnych detali architektonicznych. I tak oto Alvar Aalto promował "tapacze światta", a Le Corbusier w swe elewacje wkomponowywał "łamacze światta”.

Wraz z kryzysem modernizmu i jego powtórnym odrodzeniu w formie nowego modernizmu na przełomie XX i XX w. zmienit sie także charakter inspiracii architektonicznych. Zasady racjonalnego dostepu do światta dziennego - które byly dla pioniéóm modernizmu wręcz ideologicznie kluczowe, staty sie elementami normatywnymi. Pozwa to na o wspótczesym do problenow nasoneczien i go elem nie go jako instrumentu archick budcznego humoru i gry $z$ odbiorcami przestzeni. Paradoksalnie w czasach rozwoju echnologil cyfrowych oraz wprowadzania coraz to nowszych i wydajniejszych technologií sztucznego oświetlenia, może to doprowadzic w najblizsszych latach do nowego spojrzenia na mozllwosci, jakie daje budowanie przestrzen achick cież pozostanie najważniejszym światłem architektury po wsze czasy.

PRZYPISY:

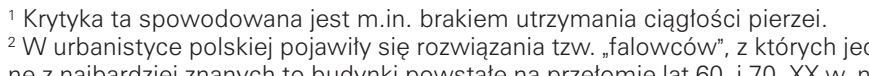
Idee te w formie koncepcyinej podjat bezpośrednio po zakończeniu I wojny
światowej w kncepcjach budynków ze stali przy i szkła Friedrichstraßße w Ber- with the need to ensure the appropriate quality of we buildings, venthation and proper hygiene-sanitary conditions - was the synym for modernity, and a part of broader social change. The variety of formal experiments in f the planning and architecture has been a result tury a mocesses. At the beginning of 20th cenbecame reformed and then aban planning quarter g the new principles of uban auat ploning, which defined access to common green quarter wheriors, and to provide the right values of surlight became an alternative. The promotion of linear, detached and tower block building layouts had been a consequence of the increase in their significance (and maybe even their leading role). Conditions resulting from the latitude on which the housing units were located were the factor which particularly influenced the ways of handling sun exposure. While in the case of the north European locations - the opening of a space for sun penetration was attempted, throughout the southern regions - attempts were made to limit its access. This influenced both the layout of individual rooms and contributed to the creation of individual archtectural details. And so had Alvar Aalto promoted the "light catchers", and Le Corbus "light breakers" in his facades.

Along with the crisis of modernism and its renaisf the 20th and 21st centuries, the chat the tur archictural inspirations has also changed. The principles of rational access to daylight - which were ideologically pivotal to the pioneers of modernism - have become the normative elements. This allows modern creators to take a more libera approach toward the problem of insolation and except making it an element of the structure of a building - incorporating it also as an architectural instrument of humour and play for the occupants of the space. Ironically, in times of digital technology development and the introduction of ever newer and more efficient artificial lighting solutions, the coming years it may lead us to a whole new perspective on the architectural space and the opportunities offered by the natural lighting which will always remain the most important archite ural light source.

ENDNOTES:

This criticism is caused, among others by the lack of the
engthwise continuity of the frontage

built at the turn of the 1960 s and 1870 s on G G are building He made these conceptual ideas immediately after the Friedrichstraike and glasswworks in Berlin.
He had been using this solution since 1930s (e. g. Finnish pavilion for a Paris World Fair in 1937 ), till the end of his ca-
reer (e. g. University Center in Jyvaskyla atrom the mid 19505 . and Culture Center in Wolfsburg from the turn of the 1950s.
and 1960s.). ${ }_{5}$ Such solutions, which were already proposed in concep-
tual sketches from the $1920 \mathrm{~s}$. Were implemented by him
among others in the pavilion L'Esprit nouveau. 
${ }^{4}$ Rozwiązanie to stosował od lat 30. XX w. (np. Pawilon Fiński na wystawę w Paryżu w 1937 r.) do końca swojej kariery (np. Centrum Uniwersyteckie w Jyväskylä z połowy lat 50. XX w., czy też Centrum Kulturalne w Wolfsburgu z przełomu lat 50 i 60. XX w.).

${ }^{5}$ Rozwiązania takie proponował już w szkicach ideowych z lat 20. XX., a zrealizował m.in. w pawilonie L'Esprit nouveau.

${ }^{6}$ Rozwiniecie tych idei była koncepcja Ville radieuse. W szczegółowych rozwiązaniach architektonicznych (np. Villencbock) zastosował on celkowy układ mieszkań, które poszerzono o tarasy

7 Zastosowanie żelbetowych łamaczy świateł stały się także elementem kompozycji elewacji w budynkach zespołu Czandigarh.

8 W początkach twórczości Nouvela odnaleźć można także inne odwołania do twórczości Le Corbusiera, które realizowała przede wszystkim w projektach willi. ${ }^{9}$ Forma łamaczy światła, zrealizowana jako nawiązanie do idei migawki aparatu fotograficznego, stała się także punktem wyjścia do innej realizacji Jeana Nouvela - projektu Instytutu Arabskiego w Paryżu.

10 Przykładem zastosowania tego typu rozwiązania był budynek Larkin Administration Building, który zaprojektował w 1903 r. Za kulminację doświadczeń Wrighta w zakresie górnego doświetlania uznać można zespół fabryczny firmy S.C. Johnson w Racine, który powstał w latach 1936-1939. Dzięki zastosowaniu innowacyjnej konstrukcji stropów grzybkowych udało mu się w projektowanych budynkach wprowadzić świetliki w formie szklanych rur, dające łagodne światło. Rozwiązanie to zastosowano także w części biurowej, które jednak ze względu na przeciekanie dachu zastapiono światłem sztucznym.

${ }^{11}$ Pośród innych idei MVRDV, w których budowę formy architektonicznej wiązać można także z inspiracjami związanymi ze sposobami naturalnego doświetlenia, wymienić należy proponowane rozwiązania budynków wysokich wyposażonych w zielone tarasy.

\section{LITERATURA:}

[1] Bauman Z., Płynna nowoczesność, Wydawnictwo literackie, Kraków, 2006.

[2] Berning M., Braum M., Giesecke J., Lütke Daldrup E., Schulz K.D. Berliner Wohnquartiere. Ein Führer durch 70 Siedlungen, Dietrich Reimer Verlag, Berlin.2003.

[3] Buttlar A., Wittmann-Englert, Dolff Bonekämper G., Baukunst der Nachkriegs moderne Architekturführer Berlin 1949-1979, Dietrich Reimer Verlag, Berlin, 2013 [4] Hilberseimer L, Groszstadt Architektur, Verlag Julius Hoffmann, Stuttgart, 1927.

[5] Le Corbusier, Urbanisme, Editions Flammarion, Paris, 2011

[6] Le Corbusier, W strone architektury, Centrum Architektury, Warszawa, 2012.

[7] Schildt G., Alvar Aalto. The Decisive Years, Rizzoli, New York, 1986.

[8] Schulz S., Schulz C.-G., Das Hansaviertel. Ikone der Moderne, Braun, Berlin, 2008.

\section{STRONY INTERNETOWE}

[1] http://www.alvaraalto.fi, dostęp z dnia 15.04.2017

[2] http://www.big.dk, dostęp z dnia 15.04.2017

[3] https://www.mvrdv.nl, dostęp z dnia 15.04.2017

[4] https://www.jeannouvel.com, dostęp z dnia 15.04.2017
${ }^{6}$ Ville radieuse was an expansion of these ideas. In detailed architectural solutions (e.g. Villencbock), he applied a cell layout of flats, which were extended by terraces.

7 The use of reinforced concrete light breakers has also become part of the facade composition of the Chandigarh buildings.

8 In the early days of Nouvel's work, other references to Le Corbusier's work, which he performed primarily in the projects of the villa, can be also found.

9 The Larkin Administration Building, designed in 1903 was an example of this type of solution. Factory complex of S.C. Johnson in Racine, which was founded in 1936-1939 is the culmination of Wright's experience in the field of high-end lighting. Thanks to the innovative design of the mushroom ceilings, he has succeeded in implementing the skylights in the design of buildings in the form of glass tubes giving a mild light. This solution was also applied in the office part, but due to roof leakage it was replaced by an artificial light source.

${ }_{10}$ Among other ideas of MVRDV, where the construction of the architectural form can also be linked to the inspirations associated with natural lighting, the proposed solutions of tall buildings with green terraces ought to be mentioned.

\section{BIBLIOGRAPHY:}

[1] Bauman Z., Płynna nowoczesność, Wydawnictwo literackie, Kraków, 2006.

[2] Berning M., Braum M., Giesecke J., Lütke Daldrup E., Schulz K.D. Berliner Wohnquartiere. Ein Führer durch 70 Siedlungen, Dietrich Reimer Verlag, Berlin.2003.

[3] Buttlar A., Wittmann-Englert, Dolff Bonekämper G., Baukunst der Nachkriegsmoderne Architekturführer Berlin 19491979, Dietrich Reimer Verlag, Berlin, 2013

[4] Hilberseimer L, Groszstadt Architektur, Verlag Julius Hoffmann, Stuttgart, 1927.

[5] Le Corbusier, Urbanisme, Editions Flammarion, Paris, 2011.

[6] Le Corbusier, W stronę architektury, Centrum Architektury, Warszawa, 2012.

[7] Schildt G., Alvar Aalto. The Decisive Years, Rizzoli, New York, 1986.

[8] Schulz S., Schulz C.-G., Das Hansaviertel. Ikone der Moderne, Braun, Berlin, 2008.

Websites

[1] http://www.alvaraalto.fi, dostęp z dnia 15.04.2017

[2] http://www.big.dk, dostep z dnia 15.04.2017

[3] https://www.mvrdv.nl, dostęp z dnia 15.04.2017

[4] https://www.jeannouvel.com, dostęp z dnia 15.04.2017 